\title{
ROLA POMORSKIEJ KOLEI METROPOLITALNEJ W KSZTAŁTOWANIU STRUKTURY PRZESTRZENNO-FUNKCJONALNEJ GDAŃSKA
}

\author{
THE EFFECT OF POMERANIAN METROPOLITAN RAILWAY \\ ON SPATIAL-FUNCTIONAL STRUCTURE OF GDAŃSK (POLAND)
}

\author{
Nr DOI: $10.25167 / \mathrm{sm} 2018.030 .03 \quad$ s. $39-55$
}

\begin{abstract}
ABSTRAKT: Koncepcja zrównoważonej mobilności, z uwagi na swój kompleksowy charakter, jest jednym z najważniejszych tematów studiów miejskich. Choć dla jej urzeczywistnienia niezbędne jest powiązanie rozwoju transportu z planowaniem przestrzennym, to kwestia ta w polskiej literaturze przedmiotu jest rzadko poruszana.

Celem niniejszego opracowania jest wstępne zbadanie dotychczasowych i określenie potencjalnych zmian w mobilności miejskiej oraz w strukturze przestrzenno-funkcjonalnej w następstwie uruchomienia Pomorskiej Kolei Metropolitalnej (PKM). Analiza publikacji naukowych, materiałów kartograficznych oraz dokumentów z zakresu programowania rozwoju lokalnego i regionalnego pozwoliła na sformułowanie następujących wniosków: (1) przebieg linii PKM odpowiada obecnemu i przyszłemu zapotrzebowaniu na przewozy wewnątrzmiejskie; (2) położenie części przystanków w oddaleniu od potencjalnych źródeł ruchu wymaga znacznie głębszej niż dotychczasowa integracji kolei z innymi środkami transportu; (3) w przyszłości planowana jest intensyfikacja zabudowy wokół przystanków PKM, co podniesie jej atrakcyjność względem transportu indywidualnego.
\end{abstract}

SŁOWA KLUCZOWE: transport miejski, kolej miejska, Gdańsk, planowanie przestrzenne, struktura przestrzenno-funkcjonalna

ABSTRACT: The concept of sustainable mobility, due to its complex nature, is one of the most important topics of urban studies. Although the link between transport development and spatial planning is necessary for its realization, this issue of the subject is rarely discussed in the Polish literature.

The purpose of this study is to initially investigate the hitherto implemented and to identify potential changes in the urban mobility and spatial-functional structure, following the launch of the Pomeranian Metropolitan Railway (PMR). The analysis of scientific publications, cartographic materials and documents on local and regional development programming allowed the following conclusions to be drawn: (i) the location of the PMR line corresponds to the current and future demand for urban transport; (ii) the location of some

* Uniwersytet Gdański, Wydział Oceanografii i Geografii, Instytut Geografii, Katedra Geografii Rozwoju Regionalnego, e-mail: marcin.polom@ug.edu.pl

** Uniwersytet Gdański, Wydział Oceanografii i Geografii, Instytut Geografii, Katedra Geografii Rozwoju Regionalnego, e-mail: maciej.tarkowski@ug.edu.pl 
railway stops far from potential traffic sources requires that the integration of railways with other means of transport should be much deeper than that to date; (iii) intensification of the development around PMR stops is planned in the future - it will increase the attractiveness of railways in comparison with individual transport.

KEY WORDS: public transport, urban railway, Gdansk, spatial-functional structure, spatial planning

\section{Wprowadzenie}

Dodatnie sprzężenie zwrotne pomiędzy rozwojem indywidualnej motoryzacji a suburbanizacją doprowadziło w miastach kapitalistycznych drugiej połowy XX w. do wykształcenia się struktury przestrzenno-funkcjonalnej zorientowanej na możliwie sprawne zaspokajanie potrzeb transportowych przy użyciu samochodu. Model ten upowszechnił się również w warunkach transformacji ustrojowej, także w Polsce. Wygoda i powszechność tego rozwiązania doprowadziły do wykształcenia się kultury autostrady (Kuligowski, Stanisz (red.) 2016), czy wręcz szerzej - systemu automobilności (Urry 2004). Tkanka miejska projektowana z myślą o sprawnym poruszaniu się samochodów ma jedną zasadniczą wadę - miasta przestały być „dla ludzi”, co negatywnie odbiło się na jakości ich życia (Gehl 2014; Parysek 2016). Zmiana strategii urbanistycznych musiała uwzględniać inne sposoby zaspokajania potrzeb transportowych. W tym kontekście pożądanym modelem mobilności miejskiej jest mobilność zrównoważona (sustainable mobility). Jej główne cechy to: wykorzystanie najnowocześniejszych technologii w celu zwiększania efektywności transportu, uwzględnianie kosztów zewnętrznych każdego rodzaju transportu w polityce cenowej, redukowanie zapotrzebowania na transport poprzez odpowiednie planowanie przestrzenne, zmiana podziału zadań przewozowych na korzyść transportu zbiorowego oraz pieszego i rowerowego, dostarczanie precyzyjnie adresowanej (spersonalizowanej) informacji dla mieszkańców (Banister 2008). Istotną rolę w równoważeniu mobilności może odgrywać kolej miejska (aglomeracyjna). W warunkach transformacji ustrojowej, w obliczu dynamicznie rozwijającej się motoryzacji indywidualnej i błędów w polityce transportowej państwa, sukcesywnie traciła ona na znaczeniu. Dopiero fundusze strukturalne UE pozwoliły na modernizację taboru i infrastruktury, co poprawiło nieco pozycję konkurencyjną omawianego środka transportu. Kwestia ta stała się także przedmiotem zainteresowania badaczy. Rola kolei aglomeracyjnej w rozwoju systemu komunikacyjnego dużych polskich miast omówiona została przez A. Koźlak (2013). Opublikowano także szereg prac dotyczących poszczególnych ośrodków: Krakowa (Bieda 2010; Ciastoń-Ciulkin, Pashkevich 2015), Wrocławia (Kruszyna 2013), Łodzi (Feltynowski, Rzeńca 2012; Giedryś, Raczyński 2014), Poznania (Bul, Rychlewski 2012), konurbacji katowickiej (Molecki, Molecki, Szymański 2009) czy Warszawy (Wojciechowski 2012). Inwestycja Pomorskiej Kolei Metropolitalnej (PKM) - pierwsza w Polsce budowana niemal od podstaw linia kolejowa od ponad 40 lat, również spotkała się z zainteresowaniem badaczy. Omówiono jej znaczenie dla systemu transportowego Gdańska i regionu metropolitalnego (Dukała 2013; Kopeć 2014; 2015), rolę w obsłudze portu lotniczego (Koźlak 2011; Gałka 2016; 
Pazdro, Judek, Skibicki 2010), wpływ na rozwój transportu tramwajowego w Gdańsku (Beister, Górny, Połom 2015) oraz kwestię integracji taryfowej w transporcie publicznym regionu metropolitalnego (Grzelec, Kołodziejski, Wyszomirski 2015).

Celem niniejszego opracowania jest odpowiedź na pytanie, w jakim stopniu uruchomienie Pomorskiej Kolei Metropolitalnej przyczyniło się do zrównoważenia mobilności miejskiej oraz do zmian w strukturze przestrzenno-funkcjonalnej Gdańska. Z uwagi na perspektywiczny charakter tej inwestycji istotne jest także pytanie o możliwe kierunki przemian miejskiej mobilności i zagospodarowania przestrzennego w przyszłości. Choć dla urzeczywistnienia koncepcji zrównoważonej mobilności powiązanie planowania rozwoju transportu z planowaniem przestrzennym jest nieodzowne (Beim 2011), to kwestia ta w polskiej literaturze przedmiotu jest stosunkowo rzadko poruszana. W wymiarze ogólnym problem ten poruszyła Koźlak (2009). Omawiany związek jest istotny w pracach poświęconych dostępności przestrzennej transportu publicznego (Gadziński, Beim 2009; Goliszek, Połom 2016) i relacji między tą dostępnością a cenami nieruchomości (Gadziński, Radzimski 2016).

Zakres przedmiotowy opracowania wyznacza omówiona już koncepcja zrównoważonej mobilności. Zakres przestrzenny ogranicza się do terytorium Gdańska, na którym skoncentrowany był główny wysiłek inwestycyjny, choć sama kolej metropolitalna obsługuje także inne miejscowości regionu metropolitalnego. Szczególna uwaga poświęcona została obszarom położonym w sąsiedztwie przystanków PKM - tam nastąpiły największe zmiany w strukturze przestrzenno-funkcjonalnej. Również na tych obszarach planowane są największe zmiany zagospodarowania. Zasadniczy zakres czasowy obejmuje dwa lata funkcjonowania PKM - od połowy 2015 do połowy 2017 r. Zwrócono również uwagę na plany dalszego rozwoju PKM i zmian zagospodarowania przestrzennego ujęte w projekcie studium uwarunkowań i kierunków zagospodarowania przestrzennego Gdańska, opublikowanym w maju 2017 r. (Studium uwarunkowań... 2017).

W pracach nad artykułem wykorzystano głównie metody kameralne polegające na analizie publikacji naukowych, materiałów kartograficznych, dokumentów z zakresu programowania rozwoju lokalnego i regionalnego. Metody kartograficzne wykorzystano w analizie zagospodarowania przestrzennego (w tym infrastruktury transportu publicznego), opierając się przede wszystkim na analizie ortofotomapy Gdańska wykonanej w 2016 r. (Interaktywny Plan Gdańska... 2017). W wymagających tego przypadkach dokonano terenowej inwentaryzacji elementów zagospodarowania przestrzennego.

Artykuł składa się z czterech części. Omówienie głównych problemów transportowych Gdańska przybliża kontekst, w jakim projektowana była i obecnie funkcjonuje linia PKM. Następnie dokonano charakterystyki przebiegu trasy, rozmieszczenia przystanków oraz potoków pasażerskich. W trzeciej części omówiono stan zagospodarowania przestrzennego sąsiedztwa przystanków PKM, wskazując na znaczące rezerwy terenowe w przypadku połowy z nich. W przyszłości mają być one stosunkowo intensywnie zagospodarowane - projektowane kierunki zagospodarowania w ogólny sposób omówiono w części czwartej. Artykuł zamykają wnioski oraz rekomendacje dotyczące problematyki dalszych badań. 


\section{Główne problemy transportowe Gdańska - kontekst budowy i funkcjonowania Pomorskiej Kolei Metropolitalnej}

Gdańsk, podobnie jak inne duże polskie miasta, boryka się z problemem niezrównoważonej mobilności. Jak wykazały Gdańskie Badania Ruchu (2016), udział transportu indywidualnego $\mathrm{w}$ podziale zadań przewozowych kształtuje się na poziomie $41 \%$ i wyraźnie przewyższa w tym względzie inne formy mobilności. Udział transportu indywidualnego w Gdańsku nie odbiega znacząco od obserwowanego w innych miastach Polski i Europy. W stosunku do niektórych jest nawet niższy. Nie zmienia to jednak faktu, że struktura podziału zadań przewozowych oparta na transporcie indywidualnym generuje szereg istotnych problemów dla funkcjonowania miasta i jego mieszkańców. Jednym z najbardziej odczuwalnych jest kongestia transportowa. W toku transformacji ustrojowej zjawisko to ulegało w polskich miastach systematycznemu nasileniu, osiągając poziom znany z większości miast krajów wysoko rozwiniętych. Było nie tylko następstwem wzrostu zamożności mieszkańców, ale pozostawało także w związku przyczynowo-skutkowym z chaotycznie postępującą suburbanizacją.

Wymienione problemy dotykają również Gdańska, gdzie po części mają lokalną specyfikę. Wynika ona ze zróżnicowanego charakteru środowiska przyrodniczego, który doprowadził do ukształtowania się pasmowych ciągów infrastruktury obsługujących dwie względnie od siebie oddzielone części miasta - dolny taras, położony w większości na aluwialnej równinie Żuław Wiślanych (północna i wschodnia część Gdańska) oraz górny taras, położony ok. 100-150 m n.p.m., na obszarze Wysoczyny Kaszubskiej (południowo-zachodnia i zachodnia część miasta - ryc. 1). W pierwszej z nich położone jest historyczne centrum miasta, współczesne centralne pasmo usługowe, tereny portowo-przemysłowe oraz gęsto zaludnione dzielnice mieszkaniowe. W drugiej dominuje funkcja mieszkaniowa, jednak znacznie bardziej rozproszona, co skutkuje niższą gęstością zaludnienia (ryc. 1) i utrudnia obsługę tego obszaru transportem publicznym. Ważnymi generatorami ruchu na tym terenie są: port lotniczy, położona w jego sąsiedztwie dzielnica przemysłowo-usługowa oraz wielkopowierzchniowe centra handlowe. Naturalną barierę oddzielającą od siebie obie części miasta stanowi krawędź wysoczyzny o urozmaiconej rzeźbie, znacznych nachyleniach stoków oraz w większości pokryta lasem (i chroniona - Trójmiejski Park Krajobrazowy). Z perspektywy rozwoju miasta ta bariera na dużą skalę pokonana została w latach 70. i 80. XX w. wraz z budową, w technologii wielkiej płyty, nowych dzielnic mieszkaniowych. Proces zasiedlenia tych terenów, w oparciu o inwestycje indywidualne lub działalność deweloperów w modelu chaotycznej, wewnętrznej suburbanizacji (Lorens 2015), kontynuowany był w okresie transformacji ustrojowej. Taki sposób rozwoju przestrzennego miasta utrudnia równoważenie miejskiej mobilności. Następująca ze znacznym opóźnieniem w stosunku do rozprzestrzeniania się zabudowy mieszkaniowej modernizacja i rozbudowa układu drogowego, a także - z jeszcze większym opóźnieniem - pozostałej infrastruktury transportu zbiorowego nie przyczyniła się do spadku znaczenia transportu indywidualnego w podziale zadań przewozowych. Wręcz przeciwnie, w stosunku 
do 2009 r. rola tego środka transportu wzrosła. Nieznacznie - o 2 pkt procentowe jednak w kierunku odwrotnym od pożądanego w modelu zrównoważonej mobilności (Gdańskie Badania... 2016).

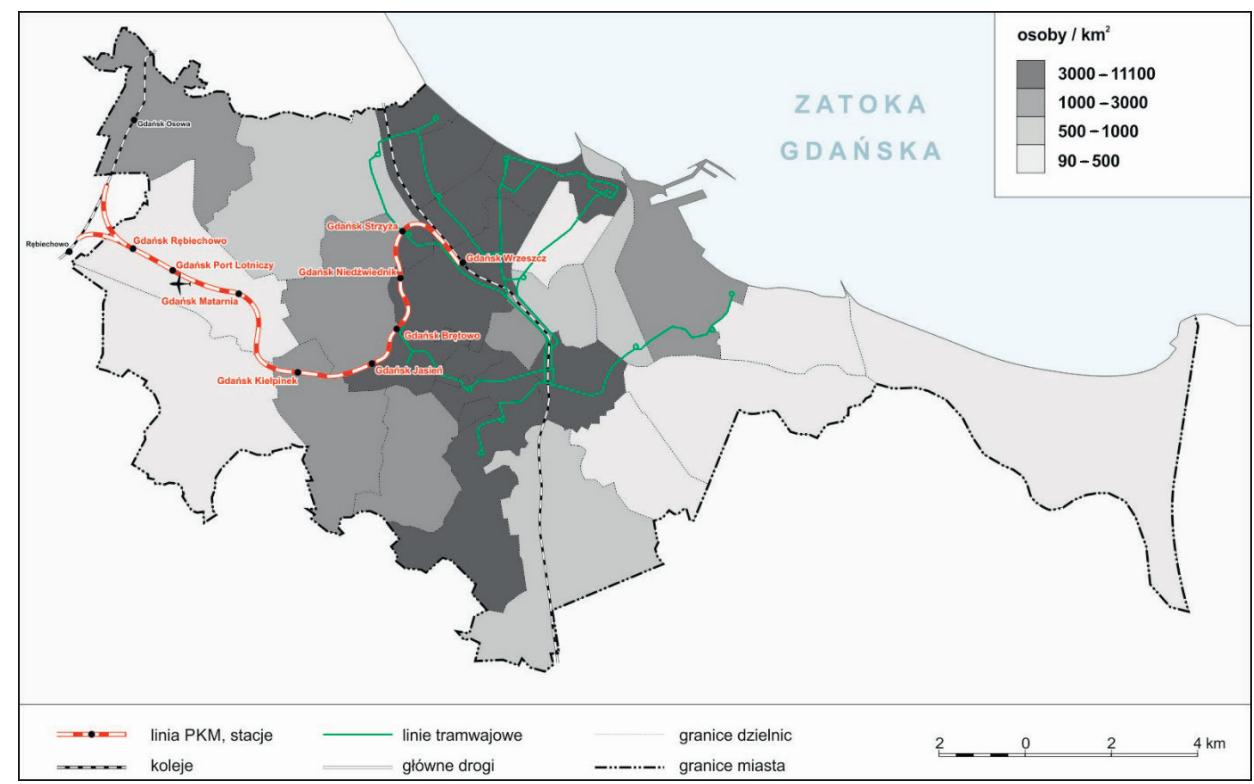

Rys. 1. Gęstość zaludnienia Gdańska w podziale na dzielnice w 2016 r. na tle przebiegu linii PKM i sieci tramwajowej

Źródło: Opracowanie własne na podstawie: PKM SA, http://www.pkm-sa.pl/glowna/ (dostęp 29 maja 2017); Gdańskie Autobusy i Tramwaje Sp. z o.o.; https://www.gait.pl/ (dostęp 29 maja 2017); dane Urzędu Miejskiego w Gdańsku, http://www.gdansk.pl/biznes/Gdansk-w-liczbach,a,33608 (dostęp 25 maja 2017).

Rozproszony charakter zagospodarowania górnego tarasu i opóźnione inwestycje infrastrukturalne utrudniają organizację efektywnego transportu zbiorowego. Następstwem tego jest większe rozpowszechnienie transportu indywidualnego. Nadmierna funkcjonalizacja, czyli dalece posunięty rozdział miejsc pracy od miejsc zamieszkania powoduje intensyfikację codziennych migracji między obiema częściami miasta stanowią one 24\% ogółu codziennych przemieszczeń wewnątrz Gdańska (Gdańskie Badania... 2016). W odpowiedzi na rosnące zapotrzebowanie sukcesywnie rozbudowywane były ciągi drogowe łączące oba tarasy. Z uwagi na trudne warunki terenowe oraz dużą wartość środowiska przyrodniczego (park krajobrazowy) takie działania są kosztowne i mogą być prowadzone na ograniczoną skalę. Ich efekty są zarazem dyskusyjne - uaktywniają uśpiony popyt na transport indywidualny (Mogridge 1997) ${ }^{1}$ oraz

1 Przykładem może być modernizacja i rozbudowa środkowego odcinka Trasy Słowackiego - jednego z ciągów łączących oba tarasy, którego przebieg zbliżony jest do trasy PKM. Znaczący wzrost przepusto- 
fragmentaryzują tkankę miejską, utrudniając poruszanie się pieszym i rowerzystom. Tego rodzaju konsekwencje wywołały wzmożoną publiczną dyskusję na temat dalszych inwestycji transportowych w mieście. Jej konkluzje znalazły odzwierciedlenie w dokumencie strategii rozwoju Gdańska do 2030 r. (Gdańsk 2030 Plus Strategia... 2014). W zakresie mobilności i transportu sformułowano jednoznaczne wyzwanie wskazujące na potrzebę zmiany podziału modalnego w kierunku spełniającego kryteria zrównoważonej mobilności miejskiej. Będąca w tym czasie w zaawansowanym stadium realizacji budowa PKM wpisywała się w przyjęty kierunek rozwoju.

\section{Geneza, przebieg i funkcjonowanie linii PKM}

Budowa linii kolejowej o charakterze metropolitalnym była planowana w Trójmieście od kilku dekad. Zakładano, że przebieg takiej linii powinien łączyć centra Gdańska i Gdyni z portami lotniczymi - istniejącym w Gdańsku-Rębiechowie i planowanym w Gdyni-Kosakowie. Pierwotnie przyjęty plan zakładał uruchomienie linii kolejowej przed organizowanymi w Polsce Mistrzostwami Europy w Piłce Nożnej w 2012 r. Nie udało się tego celu osiągnąć, ale przyjęte założenia w znacznej mierze wykonano w 2015 r. Pomorska Kolej Metropolitalna to zarówno nazwa linii kolejowej o charakterze aglomeracyjnym, jak i przyjęta nazwa spółki celowej powołanej do jej budowy i późniejszego zarządzania. Linia powstawała w latach 2013-2015, w znacznej mierze dzięki subwencji ze środków pomocowych Unii Europejskiej. Jest to odbudowana na odcinku Wrzeszcz-Kiełpinek dawna Kolej Kaszubska (nazywana Koleją Kokoszkowską), istniejąca w latach 1914-1945² oraz nowo powstała na odcinku Kiełpinek-Rębiechowo (ryc. 2).

Pierwsze opracowanie, które dawało nadzieję na odbudowę dawnego szlaku kolejowego, a tym samym możliwość zorganizowania kolei miejskiej/aglomeracyjnej, powstało w 2005 r. W maju 2007 r. przygotowano wstępne studium wykonalności, zaś w lipcu 2008 r. projekt budowy PKM został wpisany na listę projektów kluczowych w Programie Operacyjnym Infrastruktura i Środowisko. W 2009 r. wykonano docelowe studium wykonalności projektu, a 31 maja 2010 r. Sejmik Województwa Pomorskiego powołał Pomorską Kolej Metropolitalną SA w celu przygotowania i realizacji projektu

wości (dwie jezdnie po dwa pasy ruchu zamiast jednej jezdni) spowodował wzrost dobowego ruchu pojazdów z 38 tys. w 2012 r. do 52 tys. na początku 2015 r. (Korolczuk 2015). Bardzo kosztowna modernizacja przyczyniła się jedynie do ograniczenia kongestii poza godzinami szczytowego natężenia ruchu. Ponadto, przebiegając przez tereny silnie zurbanizowane, droga stała się istotną barierą dla ruchu pieszego i rowerowego w relacji przecinającej tę trasę.

2 W marcu 1945 r. wycofujące się z Gdańska niemieckie wojska, w ramach obrony, wysadziły największe wiadukty dawnej linii kolejowej. Planując blokadę, wprowadzono parowozy na wiadukty, następnie detonowano ładunki wybuchowe. Znaczne zniszczenia wojenne przyczyniły się do zaniechania odbudowy szlaku kolejowego. W 1946 r. przekreślono definitywnie tę możliwość, demontując pozostałe tory (Jursz 2013). Od lat 70. XX w. pojawiały się koncepcje odtworzenia linii kolejowej, ale nie spotykały się z aprobatą ówczesnych władz. 


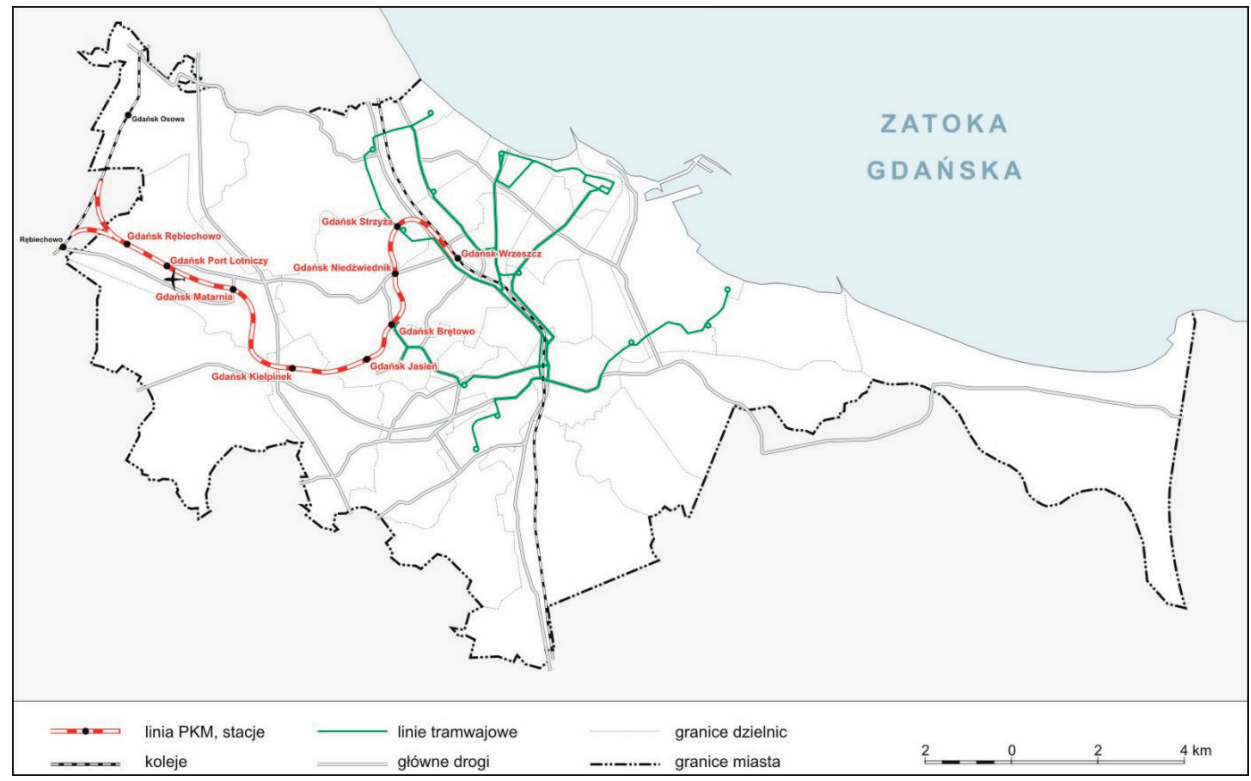

Ryc. 2. Struktura przestrzenna szynowego transportu miejskiego (tramwajowego i kolejowego) w Gdańsku (stan - 15 sierpnia 2017 r.)

Źródło: Opracowanie własne na podstawie: PKM SA, http://www.pkm-sa.pl/glowna/ (dostęp 29 maja 2017); Gdańskie Autobusy i Tramwaje Sp. z o.o.; https://www.gait.pl/ (dostęp 29 maja 2017).

(Pomorska Kolej...). W 2012 r. podpisano umowę na dofinansowanie ze środków Unii Europejskiej projektu Pomorskiej Kolei Metropolitalnej. Rzeczywiste prace budowlane trwały od 3 stycznia 2013 r. do 30 kwietnia 2015 r., a 12 czerwca 2015 r. pojawił się na torach nowej linii kolejowej pierwszy spalinowy zespół trakcyjny zakupiony do jej obsługi. Ze względu na rezygnację z elektryfikacji linii w pierwszym etapie zamówiono spalinowe autobusy szynowe w liczbie 10 sztuk. Linia została oddana do eksploatacji 1 września $2015 \mathrm{r}$.

Pomorska Kolej Metropolitalna tuż po uruchomieniu zdobyła szereg nagród, przyznawanych zarówno przez specjalistów z branży transportowej, jak i mieszkańców. Wśród takich wyróżnień można wymienić nagrodę za najważniejszą inwestycję w 2015 r. przyznawaną przez słuchaczy Radia Gdańsk. PKM stała się Inwestycją Roku 2015 w plebiscycie Pomorskie Sztormy. Duże zainteresowanie społeczne zarówno w trakcie budowy PKM, jak i po jej uruchomieniu świadczy o znacznym potencjale linii kolejowej. Aby jednak w pełni został on wykorzystany, potrzebna jest pełna integracja PKM z systemem transportowym Gdańska i obszaru aglomeracyjnego.

W ramach inwestycji zbudowano 19,5 km szlaku kolejowego, w tym $18 \mathrm{~km}$ dwutorowej linii kolejowej w kierunku przystanku Gdańsk-Osowa oraz półtorakilometrowy łącznik w kierunku Kościerzyny. Oddano do eksploatacji osiem nowych przystanków (Strzyża, Niedźwiednik, Brętowo, Jasień, Kiełpinek, Matarnia, Port Lotniczy, Rębiecho- 
wo) oraz zmodernizowano istniejący przystanek Gdańsk-Osowa i dobudowano nowy peron na stacji Gdańsk-Wrzeszcz. Wszystkie nowe przystanki oraz zmodernizowany w Gdańsku-Osowej nawiązują do jednolitej linii wizerunkowej. Maksymalna dopuszczalna prędkość szlaku kolejowego wynosi $120 \mathrm{~km} / \mathrm{h}$.

Pomorska Kolej Metropolitalna SA jako spółka celowa była odpowiedzialna za powstanie linii kolejowej, a obecnie pełni funkcję organizatora/zarządcy. W związku z tym istniała konieczność zlecenia przewozów kolejowych wykwalifikowanemu przewoźnikowi. Przetarg na obsługę linii PKM wygrała spółka PKP Szybka Kolej Miejska w Trójmieście, wchodząca w skład Grupy PKP SA, która świadczy głównie usługi na linii kolejowej o charakterze aglomeracyjnym łączącej Gdańsk z Wejherowem. Mimo iż obie linie obsługiwane przez tego samego przewoźnika mają podobny charakter, to zarówno organizacyjnie, jak i wizerunkowo pozostają całkowicie niezależne. Na linii PKM przyjęto taryfę biletową obowiązującą na liniach organizowanych przez PKP SKM w Trójmieście, a więc typowo kolejową (odcinkową) bez możliwości łatwej integracji z systemem biletowym Zarządu Transportu Miejskiego (ZTM) w Gdańsku.

W drugim etapie rozbudowy PKM przewidziano powstanie dwóch nowych przystanków w Gdyni. Zakłada się także powstanie nowego przystanku Gdańsk-Firoga, który miałby powstać w trzecim etapie rozbudowy PKM, uwzględniającym elektryfikację całej trasy z Gdańska-Wrzeszcza do Gdańska-Osowej. Także w Gdyni planuje się powstanie dwóch kolejnych przystanków.

Wraz z uruchomieniem PKM rozpoczęły kursowanie pociągi aglomeracyjne w relacjach Gdańsk Główny - Gdańsk Port Lotniczy - Gdynia Główna (oraz w relacjach skróconych, głównie do Gdańska-Wrzeszcza i Gdańska-Osowej). 1 października 2015 r. uruchomiono połączenie z Gdańska Głównego przez Port Lotniczy do Kartuz. 11 grudnia 2016 r. nastąpiły kolejne zmiany w relacjach połączeń. Uruchomiono pociągi na trasie Gdynia Główna - Gdańsk-Wrzeszcz - Gdańsk Port Lotniczy - Kościerzyna. Pociągi w tej relacji mają charakter przyspieszony i zatrzymują się tylko na wybranych stacjach (Strzyża, Jasień, Kiełpinek i Port Lotniczy), tym samym zatracając funkcję typowej kolei miejskiej.

Stosunkowo krótkie, niespełna dwuletnie doświadczenia w eksploatacji PKM, w trakcie których następowały dość częste zmiany w relacjach połączeń, a także czasowe wyłączenie części szlaku ze względu na awarie po ekstremalnych opadach, które przeszły nad Gdańskiem w nocy z 14 na 15 lipca 2016 r. ${ }^{3}$, nie pozwalają na jednoznaczną ocenę inwestycji. Faktyczny wpływ PKM na przewozy miejskie i aglomeracyjne można analizować przez liczbę jej użytkowników (ryc. 3). W okresie od października 2015 r. do czerwca 2017 r. zauważalny jest stały trend wzrostu liczby pasażerów we wszystkich

\footnotetext{
${ }^{3}$ Ze względu na znaczną liczbę usterek szlaku kolejowego - łącznie 688 awarii różnego typu, w tym 56 poważnych, wymagających naprawy przed ponownym uruchomieniem przewozów, cała linia była wyłączona z eksploatacji do 19 lipca, kiedy nastąpiło częściowe przywrócenie ruchu na odcinku Gdańsk-Osowa - Gdańsk Port Lotniczy. 31 sierpnia rozpoczęto testy pozostałego odcinka, a uruchomienie przewozów w ograniczonym zakresie nastąpiło 4 września. Ruch do Gdyni wznowiono 7 września, a połączenia do Kartuz 31 października.
} 


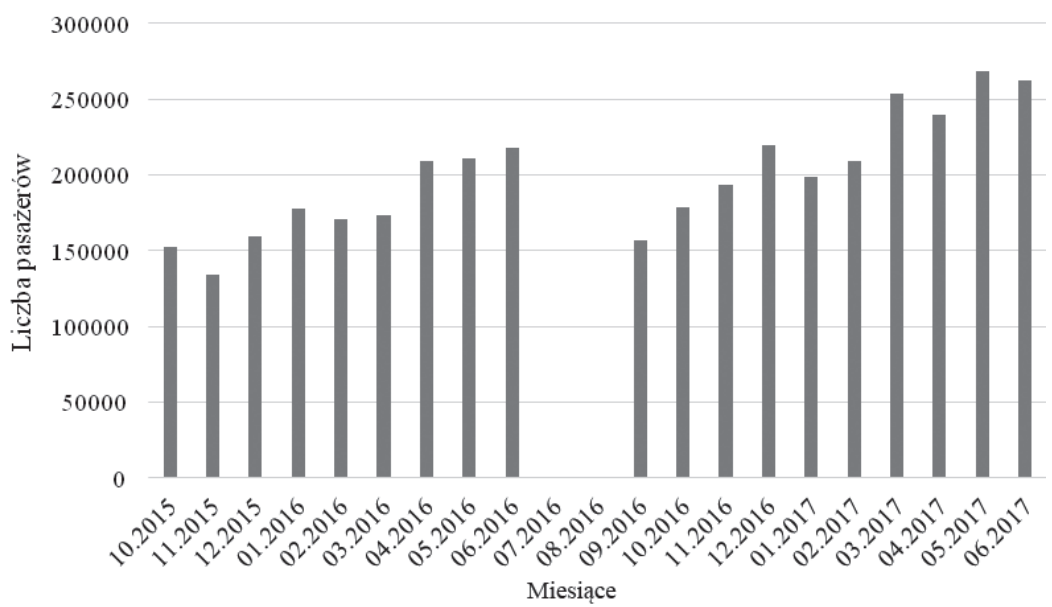

Ryc. 3. Liczba pasażerów PKM w poszczególnych miesiącach

Źródło: opracowanie własne na podstawie danych PKM SA, http://www.pkm-sa.pl/glowna/ aktualnosci/blisko-15-mln-pasazerow-na-linii-pkm-w-pierwszej-polowie-2017-r/ (dostęp 25 lipca 2017).

relacjach liczonych wspólnie. Należy jednak spojrzeć bardziej szczegółowo na to zestawienie pod kątem liczby pasażerów korzystających z połączeń o charakterze wewnątrzmiejskim i metropolitalnym, dojeżdżających do Trójmiasta z Kartuz i Kościerzyny. Według danych PKM SA liczba pasażerów w ruchu aglomeracyjnym (Gdańsk i Gdynia) spadła w ujęciu rok do roku ze 151,6 tys. w czerwcu 2016 r. do 141,1 tys. w czerwcu 2017 r., zaś w połączeniach do Kartuz i Kościerzyny notowano wzrosty. Liczba pasażerów w połączeniu Gdańsk-Kartuzy wzrosła w tym samym okresie z 26,5 tys. pasażerów do 65,0 tys., zaś w relacji Gdynia-Kościerzyna nastąpiła zmiana liczby użytkowników z 40,0 tys. do 56,5 tys.

Według danych zarządcy linii najbardziej popularnymi przystankami na terenie Gdańska są Jasień i Kiełpinek (pasażerowie wsiadający w szczycie porannym i wysiadający w szczycie popołudniowym). Odwrotnie sytuacja wygląda w przypadku stacji Gdańsk-Wrzeszcz - największa liczba pasażerów PKM korzysta z niej w szczycie porannym (wysiadając z pociągów) i popołudniowym (wsiadając). Analizując dotychczasowe doświadczenia z eksploatacji linii PKM, można wnioskować, że największy potencjał w ruchu wewnątrzmiejskim mają przystanki Jasień i Kiełpinek (osiedla mieszkaniowe) oraz Port Lotniczy, a w ruchu aglomeracyjnym - stacje początkowe Kartuzy i Kościerzyna oraz stacja pośrednia w Żukowie.

\section{Dotychczasowe zagospodarowanie przestrzenne sąsiedztwa przystanków PKM}

Rekonstrukcja linii kolejowej po historycznym śladzie rodzi problem niedopasowania jej przebiegu do aktualnego zagospodarowania przestrzennego, którego elementy 
stanowią potencjalne źródło ruchu pasażerskiego. Taki problem występuje w przypadku linii PKM. Tylko Wrzeszcz i Strzyża - dwa przystanki zlokalizowane na dolnym tarasie w obrębie centralnego pasma usługowego - leżą w terenie silnie zurbanizowanym o rozwiniętej funkcji mieszkaniowej, usługowej i dobrej dostępności do innych środków transportu (tabela 1). Kolejne dwa przystanki - Niedźwiednik i Brętowo - położone są w strefie krawędziowej wysoczyzny. Warunki terenowe ograniczają możliwości zagospodarowania ich najbliższego sąsiedztwa. Większość zabudowy mieszkaniowej

Tabela 1

Zagospodarowanie przestrzenne sąsiedztwa (promień 660 m) przystanków PKM w Gdańsku

(stan na koniec lipca 2017 r.)

\begin{tabular}{|c|c|c|c|c|}
\hline $\begin{array}{l}\text { Przysta- } \\
\text { nek }\end{array}$ & $\begin{array}{c}\text { Dominująca } \\
\text { zabudowa } \\
\text { mieszkaniowa }\end{array}$ & $\begin{array}{c}\text { Dominujące ponadlokal- } \\
\text { ne funkcje usługowe lub } \\
\text { przemysłowe }\end{array}$ & $\begin{array}{l}\text { Orientacyjny od- } \\
\text { setek powierzch- } \\
\text { ni zabudowanej }\end{array}$ & $\begin{array}{c}\text { Integracja } \\
\text { z innymi środkami } \\
\text { transportu }\end{array}$ \\
\hline Wrzeszcz & wielorodzinna & $\begin{array}{l}\text { centralne pasmo usługo- } \\
\text { we - trzy galerie handlo- } \\
\text { we, biurowce, hotel, ciągi } \\
\text { mniejszych obiektów } \\
\text { usługowych }\end{array}$ & $>75 \%$ & $\begin{array}{l}\text { kolej miejska i daleko- } \\
\text { bieżna; } \\
\text { transport miejski - głów- } \\
\text { ny węzeł przystankowy; } \\
\text { płatne miejsca parkin- } \\
\text { gowe }\end{array}$ \\
\hline Strzyża & $\begin{array}{l}\text { mieszana } \\
\text { z przewagą } \\
\text { jednorodzin- } \\
\text { nej }\end{array}$ & $\begin{array}{l}\text { kampus uniwersytecki, } \\
\text { zajezdnia tramwajowa, } \\
\text { centrum handlowe, } \\
\text { centrum sportu, salony } \\
\text { samochodowe }\end{array}$ & $>75 \%$ & $\begin{array}{l}\text { przystanek tramwajowy } \\
\text { na pętli i przelotowy }\end{array}$ \\
\hline $\begin{array}{l}\text { Niedź- } \\
\text { wiednik }\end{array}$ & wielorodzinna & $\begin{array}{l}\text { szpital psychiatryczny, } \\
\text { cmentarz komunalny, ze- } \\
\text { spół szkół niepublicznych }\end{array}$ & $50 \%$ & przystanek autobusowy \\
\hline Brętowo & mieszana & brak & $25 \%$ & $\begin{array}{l}\text { końcowy przystanek } \\
\text { tramwajowy i przystanek } \\
\text { autobusowy }\end{array}$ \\
\hline Jasień & wielorodzinna & brak & $25 \%$ & $\begin{array}{l}\text { końcowy przystanek } \\
\text { autobusowy; } \\
\text { miejsca parkingowe }\end{array}$ \\
\hline Kiełpinek & $\begin{array}{l}\text { mieszana } \\
\text { z przewagą } \\
\text { wielorodzinnej }\end{array}$ & centrum handlowe & $50 \%$ & $\begin{array}{l}\text { końcowy przystanek } \\
\text { autobusowy; } \\
\text { miejsca parkingowe }\end{array}$ \\
\hline Matarnia & wielorodzinna & $\begin{array}{l}\text { przedsiębiorstwa przemy- } \\
\text { słowe i usługowe }\end{array}$ & $25 \%$ & $\begin{array}{l}\text { przystanek autobusowy; } \\
\text { miejsca parkingowe }\end{array}$ \\
\hline $\begin{array}{l}\text { Port } \\
\text { Lotniczy }\end{array}$ & brak & biurowce, hotel & $25 \%$ & $\begin{array}{l}\text { transport lotniczy; } \\
\text { końcowy przystanek } \\
\text { autobusowy }\end{array}$ \\
\hline $\begin{array}{l}\text { Rębie- } \\
\text { chowo }\end{array}$ & $\begin{array}{l}\text { jednorodzinna } \\
\text { rozproszona }\end{array}$ & pola uprawne & $<25 \%$ & brak \\
\hline
\end{tabular}

Źródło: opracowanie własne na podstawie analizy kartograficznej i inwentaryzacji terenowej. 
i ponadlokalnych funkcji usługowych umiejscowiona jest w odleglejszej części obszaru uznanego za sąsiedztwo przystanków (okrąg o promieniu $660 \mathrm{~m}$ ). Poruszanie się między tymi przystankami a pozostałymi obiektami wymaga w większości przypadków pokonywania znacznych deniwelacji, co może zniechęcać do korzystania z oferty przewozowej PKM.

Na górnym tarasie położonych jest pięć przystanków. Najbliższe sąsiedztwo trzech z nich - Jasienia, Kiełpinka i Rębiechowa - jest zagospodarowane w ograniczonym stopniu. W pierwszych dwóch przypadkach rozbudowywane są osiedla mieszkaniowe, w których dominuje zabudowa wielorodzinna. Najintensywniejsze zagospodarowanie cechuje sąsiedztwo przystanku Kiełpinek. Funkcjonuje tam duże osiedle mieszkaniowe z przewagą zabudowy wielorodzinnej oraz wielkopowierzchniowe centrum handlowe. Przystanek położony jest jednak na skraju tych terenów, co zmniejsza atrakcyjność PKM jako środka transportu miejskiego. Najmniej intensywnym zagospodarowaniem odznaczają się tereny położone w sąsiedztwie przystanku Rębiechowo (tabela 1). Dominują tam użytki rolne. Występuje także silnie rozproszona jednorodzinna zabudowa mieszkaniowa, w większości położona już poza granicami Gdańska. Przystanek leży bowiem przy granicy z gminą Żukowo, w sąsiedztwie podlegającej silnym procesom suburbanizacyjnym miejscowości Banino.

Bardziej intensywnym zagospodarowaniem, w porównaniu do trzech wymienionych obszarów, wyróżnia się sąsiedztwo przystanków Matarnia i Port Lotniczy. Pierwszy z nich obsługuje skraj dużej dzielnicy przemysłowej i osiedla mieszkaniowego. Z uwagi na jego peryferyjne położenie nie odgrywa większej roli w obsłudze transportowej tych obszarów. Sąsiedztwo drugiego z przystanków stanowi port lotniczy - obiekt kluczowy dla funkcjonowania tej linii. Decyzja o jej odbudowie uzasadniona była m.in. potrzebą poprawy dostępności do tego obiektu. Ponadto istnieją tam parkingi lotniskowe, hotel, a także obiekty położone na skraju dzielnicy biurowej, której rdzeń w postaci siedziby gdańskiego oddziału międzynarodowej korporacji „Intel” zlokalizowany jest już poza zasięgiem dobrej dostępności do przystanku.

Analiza zagospodarowania przestrzennego sąsiedztwa przystanków PKM wskazuje na perspektywiczny charakter tej inwestycji. Po części wyprzedza ona prognozowany wzrost popytu, co w polskich warunkach raczej jest rzadkością. O znaczeniu PKM jako środka transportu miejskiego zadecyduje skala dalszych inwestycji mieszkaniowych w pobliżu przystanków, organizacja przewozów autobusowych i tramwajowych i ich koordynacja z ofertą przewozową kolei oraz rozwój systemu park and ride.

\section{Dostosowanie infrastruktury i organizacji transportu zbiorowego}

Budowa nowej linii kolei miejskiej, która w założeniach władz samorządowych ma odgrywać rolę kręgosłupa komunikacyjnego, powinna się wiązać ze znacznymi zmianami w strukturze funkcjonalnej transportu zbiorowego. Podejście sprzyjające równoważeniu miejskiej mobilności zakłada przejęcie przez kolej wiodącej roli w codziennych podróżach mieszkańców. Jednak aby taka sytuacja mogła zaistnieć, 
konieczne jest zintegrowanie funkcjonalne i organizacyjne istniejącego transportu miejskiego z nową linią kolejową. Ze względu na właściciela inwestycji kolejowej Urząd Marszałkowski Województwa Pomorskiego - a więc podmiot niezwiązany bezpośrednio z organizacją transportu publicznego na terenie Gdańska, należało oczekiwać daleko idących uzgodnień w zakresie organizacji transportu po oddaniu inwestycji kolejowej do eksploatacji.

W ramach przygotowań do uruchomienia Pomorskiej Kolei Metropolitalnej organizator transportu miejskiego w Gdańsku - Zarząd Transportu Miejskiego - przygotował koncepcję zmian siatki połączeń autobusowych i tramwajowych. Głównym zamierzeniem była taka zmiana przebiegu linii, aby różne środki komunikacji wzajemnie się uzupełniały, a nie konkurowały ze sobą. Zaplanowano więc likwidację linii autobusowych prowadzących do centrum miasta z rejonów przystanków PKM, reorganizację dziesięciu linii w celu połączenia ich z tymi przystankami, aby nadać im dowozowy charakter, oraz utworzenie jednej nowej linii o takim charakterze. Dzięki proponowanym rozwiązaniom mieszkańcy osiedli bardziej oddalonych od przebiegu trasy kolejowej zyskaliby łatwiejszy dostęp do przystanków PKM, co miało się przyczynić do wzrostu liczby pasażerów korzystających z transportu zbiorowego. Zamierzeniem władz samorządowych było właśnie ograniczenie konkurencji między powstającą koleją metropolitalną a transportem autobusowym i tramwajowym. Jednak wraz z uruchomieniem przewozów PKM w znacznej mierze ograniczono wprowadzanie zmian w funkcjonowaniu transportu zarządzanego przez ZTM w Gdańsku. Takie działania motywowano koniecznością zbadania zainteresowania mieszkańców nową linią kolejową, a także chęcią wprowadzania zmian ewolucyjnie, a nie w nagły sposób. Trudno jednak oceniać takie podejście jako służące równoważeniu miejskiej mobilności. Zainteresowanie nową trasą kolejową, oddaloną ze względów terenowych od dotychczasowych obszarów zamieszkania, jest wprost proporcjonalne do możliwości uzyskania komfortowych i szybkich przesiadek między różnymi środkami transportu. Przejazd multimodalny może być atrakcyjny dla mieszkańców, gdy wygrywa krótszym czasem przejazdu z pojedynczym środkiem komunikacji.

Większość wprowadzanych zmian wraz z uruchomieniem PKM dotyczyła linii tramwajowych, w związku z oddaniem do eksploatacji przedłużenia trasy z pętli przy ul. Kartuskiej na Siedlcach do przystanku Brętowo. Stworzono tym samym możliwość przesiadek door-to-door między tramwajem a pociągiem PKM, co w szczególności miało być atrakcyjne dla mieszkańców pobliskiego osiedla Morena. Do przystanku Brętowo przedłużono linię tramwajową, która w okresie szczytów przewozowych funkcjonuje co 10 min. Zmianie uległy przebiegi części linii autobusowych. Wraz z otwarciem linii kolejowej równolegle zbudowano węzły integracyjne przy przystankach Jasień i Kiełpinek ${ }^{4}$. Przy przystanku Matarnia utrzymano przystanek dla kursujących tą

\footnotetext{
4 Do przystanku PKM Jasień wydłużono cztery linie autobusowe. Do drugiego z wymienionych przystanków nie planowano poprowadzenia nowych linii komunikacyjnych, motywując takie działanie faktem, że osiedle znajduje się w zasięgu pieszego dojścia do przystanku. Decyzja ZTM w Gdańsku nie spodobała
} 
trasą dwóch linii autobusowych. Z kolei w odniesieniu do przystanku PKM zlokalizowanego w rejonie lotniska zmian nie wprowadzono, pozostawiając dotychczasowe trzy linie, tym samym rezygnując z likwidacji przynajmniej jednej z nich. Istniejące przed powstaniem PKM linie autobusowe w dzielnicy Osowa pozostawiono w dotychczasowych przebiegach, zapewniając o wystarczającym poziomie obsługi przystanku PKM.

Powstanie Pomorskiej Kolei Metropolitalnej wymusiło reorganizację funkcjonowania transportu miejskiego w rejonie przebiegu linii kolejowej. Władze Gdańska przy współfinansowaniu unijnym zbudowały węzły integracyjne przy przystankach Jasień i Kiełpinek. Istotną inwestycją było przedłużenie linii tramwajowej z Siedlec przez Morenę w kierunku przystanku Brętowo, gdzie wybudowano węzeł przesiadkowy. Z punktu widzenia organizacji transportu wykonane zmiany w połączeniach wydają się zbyt ograniczone, gdyż nie zlikwidowały konkurencji różnych środków transportu. Najbardziej istotnym mankamentem funkcjonowania nowego układu komunikacyjnego jest jednak brak integracji taryfowej. Ze względu na różnych zarządców systemów nie zaistniała dotychczas możliwość pełnej integracji taryf komunikacyjnych ${ }^{5}$.

\section{Perspektywy dalszych przekształceń zagospodarowania przestrzennego}

Jak już zauważono, rekonstrukcja linii PKM po historycznym śladzie skutkowała częściowym niedopasowaniem lokalizacji przystanków względem głównych źródeł ruchu. Jedną z konsekwencji takiego stanu rzeczy jest konieczność intensyfikacji zagospodarowania terenów położonych w sąsiedztwie przystanków PKM. Proces taki najprawdopodobniej będzie miał miejsce. Od początku 2015 r. prowadzone są prace nad nowym studium uwarunkowań i kierunków zagospodarowania przestrzennego Gdańska. Jako jeden z głównych powodów rozpoczęcia tych prac wskazano właśnie oddanie do użytku linii PKM, co implikuje konieczność zmian w polityce przestrzennej Gdańska (Studium uwarunkowań... 2017). W projekcie studium podkreślono potrzebę kontynuacji dotychczasowej polityki przestrzennej, zwracając jednocześnie uwagę na potrzebę zmian w kierunkach zagospodarowania terenów w rejonie przystanków PKM. Przekształcenia mają polegać na zmianie przeznaczenia terenów planowanych wcześniej pod zieleń i inne ekstensywne funkcje na funkcję mieszkaniowo-usługową. Rozwój funkcji mieszkaniowej przewidywany jest przede wszystkim w sąsiedztwie przystanków Jasień i Kiełpinek. O ile zabudowa mieszkaniowa nowych dzielnic górnego tarasu ma się charakteryzować niską intensywnością i wyższym odsetkiem powierzchni biologicznie czynnych, o tyle dla terenów sąsiadujących z przystankami PKM prze-

\footnotetext{
się lokalnej społeczności, która wywalczyła przedłużenie linii 164, a także w 2016 r. powstanie kolejnej, o charakterze osiedlowym.

${ }^{5}$ Rolę wspólnego biletu spełnia jedynie bilet metropolitalny dystrybuowany przez Metropolitalny Związek Komunikacyjny Zatoki Gdańskiej. Jest to rozwiązanie słabo rozpowszechnione, stosunkowo drogie i mało popularne wśród mieszkańców.
} 
widziano odstępstwo od tej zasady - zabudowa ma być bardziej intensywna. Z kolei w sąsiedztwie przystanku Matarnia oraz Portu Lotniczego planowany jest rozwój funkcji produkcyjno-usługowo-logistycznej. W otoczeniu lotniska dla przedsięwzięć komercyjnych i publicznych ma być przeznaczonych ponad 140 ha terenów inwestycyjnych (Studium uwarunkowań... 2017).

W projekcie studium zakłada się pogłębienie integracji systemu transportowego miasta i całego regionu metropolitalnego. Na tym polu PKM również ma odgrywać ważną rolę. Według przyjętej na potrzeby studium klasyfikacji węzłów integracyjnych przystanek Port Lotniczy ma znaczenie krajowe, przystanek Wrzeszcz - regionalne, a Rębiechowo - metropolitalne. Dwa kolejne - Jasień i Brętowo - zaklasyfikowane zostały jako węzły integracyjne o znaczeniu lokalnym. Pozostałe przystanki również mają mieć charakter zintegrowany. Ponadto otwarta pozostaje kwestia poprowadzenia linii tramwajowej wzdłuż torowiska PKM na odcinku Strzyża-Brętowo albo, o ile w przyszłości pozwolą na to przepisy, udostępnienia odcinka istniejącego torowiska dla ruchu tramwajowego (Studium uwarunkowań... 2017). Ponadto przy okazji elektryfikacji linii ma być wybudowany przystanek Gdańsk-Firoga. Ułatwi on dostęp do centrum biurowego będącego siedzibą gdańskiego oddziału międzynarodowej korporacji „Intel”.

\section{Wnioski}

Pomorska Kolej Metropolitalna to inwestycja istotna nie tylko dla Gdańska, ale także dla województwa pomorskiego, a w symbolicznym sensie dla całej Polski. To pierwsza od ponad 40 lat linia kolejowa zbudowana od podstaw. Doświadczenia z jej budowy i eksploatacji mogą być inspirujące dla innych dużych miast i sprzyjać równoważeniu miejskiej mobilności. Z punktu widzenia rozwoju regionu PKM stanowi ważny element kolei aglomeracyjnej. Inwestorem i zarządcą linii jest Samorząd Województwa Pomorskiego. W naturalny sposób wymusza to jego współpracę z samorządami lokalnymi, co powinno sprzyjać spójności sieci i efektywności oraz atrakcyjności transportu zbiorowego. Jak pokazuje przykład PKM, współpraca ta nie przyniosła jak dotąd zadowalających efektów - nie zlikwidowano konkurencji między różnymi środkami transportu publicznego, choć udało się ją ograniczyć. Nie dokonano również integracji taryfowo-biletowej pomiędzy PKM a miejskim transportem publicznym. Są to mankamenty poważnie ograniczające konkurencyjność transportu publicznego względem indywidualnego. Mimo tych problemów PKM to bardzo istotna inwestycja dla funkcjonowania transportu zbiorowego w Gdańsku, przede wszystkim dlatego, że łączy oba tarasy miasta. W tej relacji odbywa się blisko 1/4 codziennych podróży mieszkańców. Trwający niemal od początku transformacji ustrojowej proces wewnętrznej suburbanizacji skutkuje zwiększeniem ich liczby. Ograniczone warunkami terenowymi możliwości rozbudowy połączeń drogowych uniemożliwiają zaspokojenie rosnących potrzeb transportowych. Oddanie do użytku linii PKM stwarza możliwości złagodzenia tych problemów. Obecnie pozytywny wpływ tej inwestycji jest ograniczony. Z uwagi na przebieg linii, uwarunkowany terenowo i historycznie, połowa przystanków położona jest 
w znacznym oddaleniu od potencjalnych obiektów generujących ruch pasażerski. To istotnie obniża atrakcyjność oferty przewozowej PKM. Częściowym rozwiązaniem tego problemu jest integracja z innymi środkami transportu miejskiego. Jak już zauważono, jej poziom nie jest jednak zadowalający. Co ważne, PKM postrzegana jest przez władze miasta jako istotny element infrastruktury transportu, wokół którego intensyfikowane będzie zagospodarowanie przestrzenne. Stanowi zatem inwestycję, która po części wyprzedza popyt na usługi transportowe. Stwarza to szansę na ukształtowanie wśród użytkowników terenów, które będą zagospodarowane, nawyku korzystania z transportu zbiorowego. Jest to łatwiejsze niż nakłanianie do zmiany zachowań - szczególnie wiążących się z ograniczeniem korzystania z prywatnego samochodu osobowego na rzecz pociągu, tramwaju czy autobusu. Takie zmiany ma wspierać dalsza integracja transportu m.in. w oparciu o węzły zlokalizowane w sąsiedztwie przystanków PKM.

Biorąc pod uwagę samą skalę inwestycji, należy stwierdzić, że sprzyja ona kształtowaniu modelu zrównoważonej mobilności miejskiej w Gdańsku. Funkcjonowanie PKM w niewielkim stopniu, ale jednak ogranicza ruch samochodów osobowych w relacji dolny-górny taras miasta. To podnosi efektywność transportu miejskiego. Wokół połowy przystanków istnieją znaczne rezerwy terenowe. Ich zagospodarowanie pozwoli w pełni wykorzystać zdolności przewozowe PKM, a tym samym ograniczyć zapotrzebowanie na transport indywidualny. Jest to zarazem przejaw pożądanego, z punktu widzenia koncepcji zrównoważonej mobilności, powiązania rozwoju transportu z planowaniem i zagospodarowaniem przestrzennym.

Przeprowadzona analiza pozwala również wskazać przynajmniej dwa problemy wymagające dalszych badań. Po pierwsze - czy tereny wokół przystanków rzeczywiście okażą się atrakcyjne dla inwestorów i nowych mieszkańców? Jaka będzie dynamika zabudowy i komercjalizacji? Jakie szczegółowe funkcje będą dominowały na tych terenach? Jak kształtować będą się ceny nieruchomości? Czy będą odzwierciedlać rentę położenia? Po drugie - czy PKM przyczyni się do uatrakcyjnienia oferty transportu miejskiego? Czy liczba pasażerów zacznie rosnąć, czy zostanie przełamany niekorzystny trend wzrostu transportu indywidualnego w strukturze pracy przewozowej?

\section{Bibliografia}

Banister D., 2008, The sustainable mobility paradigm, “Transport Policy” 15.

Beim M., 2011, Sprawny transport publiczny w polskich miastach, Instytut Sobieskiego, Warszawa.

Beister M., Górny J., Połom M., 2015, Rozwój infrastruktury tramwajowej w Polsce w okresie członkostwa w Unii Europejskiej, „Technika Transportu Szynowego” 7/8.

Bieda K., 2010, Kolej aglomeracyjna - nowy czynnik w rozwoju przestrzennym Krakowa, „Czasopismo Techniczne. Architektura" nr 107.

Bul R., Rychlewski J., 2012, Kolej aglomeracyjna jako podstawowy element systemu transportu publicznego w aglomeracji poznańskiej, [w:] Szymczak M. (red.), Transport publiczny w aglomeracji poznańskiej propozycje usprawnień, Bogucki Wydawnictwo Naukowe, Poznań, s. 35-49.

Ciastoń-Ciulkin A., Pashkevich A., 2015, Znaczenie oferty przewozowej w kształtowaniu ruchu pasażerskiego na przykładzie kolejowej linii aglomeracyjnej na trasie Kraków Gtówny-Wieliczka Rynek Kopalnia, „Zeszyty Naukowo-Techniczne Stowarzyszenia Inżynierów i Techników Komunikacji w Krakowie” nr 3(107). 
Dukała D., 2013, Pomorska Kolej Metropolitalna: rewolucja w trójmiejskim transporcie publicznym, „Geoinżynieria: drogi, mosty, tunele" nr 1.

Feltynowski M., Rzeńca P., 2012, Analiza porównawcza transportu kolejowego i samochodowego waglomeracji tódzkiej w kontekście realizacji projektu Łódzkiej Kolei Aglomeracyjnej, [w:] Feltynowski M., Kina E., Niepiekło B., Tomaszewska A. (red.), Po kolei. Miejsca, wyzwania, inspiracje, SKN Spatium, Łódź, s. 263-276.

Gadziński J., Beim M., 2009, Dostępność przestrzenna lokalnego transportu publicznego w Poznaniu, „Transport Miejski i Regionalny" nr 5.

Gadziński J., Radzimski A., 2016, The first rapid tram line in Poland: How has it affected travel behaviours, housing choices and satisfaction, and apartment prices?, "Journal of Transport Geography” No. 5.

Gałka P., 2016, Zastosowanie koncepcji Airport Link w Polsce na przykładzie Pomorskiej Kolei Metropolitalnej, „Zeszyty Naukowe Uniwersytetu Gdańskiego. Ekonomika Transportu i Logistyka” nr 61.

Gdańsk 2030 Plus Strategia Rozwoju Miasta, 2014, Urząd Miejski w Gdańsku, Gdańsk.

Gdańskie Badania Ruchu 2016 wraz z opracowaniem transportowego modelu symulacyjnego Gdańska. Raport III. Raport z przeprowadzenia badań i pomiarów, 2016, Urząd Miejski w Gdańsku, Gdańsk.

Gehl J., 2014, Miasta dla ludzi, Wydawnictwo RAM, Kraków.

Giedryś A., Raczyński J., 2014, Łódzka Kolej Aglomeracyjna - the new railway system for the Lodz agglomeration, „TTS Technika Transportu Szynowego” nr 21.

Goliszek S., Połom M., 2016, Wpływ budowy nowej linii tramwajowej w Olsztynie na zmianę dostępności transportem zbiorowym, „Acta Scientrium Polonorum, Administratio Locorum” 15(3).

Grzelec K., Kołodziejski H., Wyszomirski O., 2015, Koncepcja integracji taryfowej transportu zbiorowego w Obszarze Metropolitalnym Trójmiasta, „Zeszyty Naukowe Uniwersytetu Gdańskiego. Ekonomika Transportu i Logistyka" nr 57.

Jursz H., 2013, Koleja z Wrzeszcza na Kaszuby, Oskar, Gdańsk.

Kopeć K., 2014, Pomorska Kolej Metropolitalna jako element zrównoważonego rozwoju systemu transportowego aglomeracji gdańskiej, „Zeszyty Naukowe. Problemy Transportu i Logistyki” nr 28.

Kopeć K., 2015, Pomorska Kolej Metropolitalna jako nowy element ksztattowania komunikacji w aglomeracji gdańskiej, „Logistyka” nr 3.

Korolczuk M., 2015, Duży wzrost ruchu na ul. Słowackiego, www.trojmiasto.pl (dostęp 19 lipca 2016).

Koźlak A., 2009, Kierunki zmian w planowaniu rozwoju transportu w miastach jako efekt dążenia do zrównoważonego rozwoju, „Transport Miejski i Regionalny” 7/8.

Koźlak A., 2011, Perspektywy włączenia transportu kolejowego w obsługę portów lotniczych w Polsce, „Logistyka" nr 6.

Koźlak A., 2013, Kolej aglomeracyjna jako podstawa systemu komunikacyjnego obszarów metropolitalnych w Polsce, „Studia Ekonomiczne. Zeszyty Naukowe Uniwersytetu Ekonomicznego w Katowicach” nr 143.

Kuligowski W., Stanisz A. (red.), 2016, Cultures of motorway. Localities through mobility as an anthropological issue, TIPI, Wielichowo.

Kruszyna M., 2013, Integracja transportu publicznego na bazie kolei dla dużej i koncentrycznej aglomeracji (Aglomeracja Wroctawska), „Przegląd Komunikacyjny” nr 11.

Lorens P., 2015, Scenariusze rozwoju przestrzennego obszaru metropolitalnego Trójmiasta, „Rozwój Regionalny i Polityka Regionalna" nr 29.

Molecki A., Molecki B., Szymański K., 2009, Kolej aglomeracyjna w Górnośląskim Okręgu Przemystowym analiza niewykorzystanego potencjatu, „Rynek Kolejowy” nr 3.

Mogridge M.J., 1997, The self-defeating nature of urban road capacity policy: A review of theories, disputes and available evidence, "Transport Policy" 4.

Parysek J.J., 2016, Dla kogo miasto? Dla ludzi czy dla samochodów?, „Studia Miejskie” t. 23.

Pazdro P., Judek S., Skibicki J., 2010, Kolej metropolitalna w trójmieście - inne spojrzenie, „Zeszyty Naukowe Wydziału Elektrotechniki i Automatyki Politechniki Gdańskiej” nr 27.

Studium uwarunkowań i kierunków zagospodarowania miasta Gdańska. Projekt z dnia 30.05.2017 r., 2017, Biuro Rozwoju Gdańska, Gdańsk.

Urry J., 2004, The 'system' of automobility, “Theory, Culture \& Society” 4/5.

Wojciechowski A., 2012, Miejsce Warszawskiej Kolei Dojazdowej w systemie logistyki miejskiej Aglomeracji Warszawskiej, „Logistyka” nr 3. 
Gdańskie Autobusy i Tramwaje Sp. z o.o., www.gait.pl (dostęp 12 sierpnia 2017). http://www.gdansk.pl/biznes/Gdansk-w-liczbach,a,33608 (dostęp 25 maja 2017). Interaktywny Plan Gdańska, www.mapa.gdansk.gda.pl (dostęp 15 lipca 2017). Pomorska Kolej Metropolitalna S.A., www.pkm-sa.pl (dostęp 15 sierpnia 2017). 